\title{
Crítica de cinema e patrulha ideológica: o caso Xica da Silva de Carlos Diegues ${ }^{1}$
}

\section{Film criticism and ideological patrol: the case of Carlos Diegues' Xica da Silva}

\author{
Margarida Maria Adamatti \\ Doutora pela Escola de Comunicações e Artes da Universidade de São Paulo (ECA-USP). \\ <mmadamatti@hotmail.com>
}

\section{RESUMO}

O cineasta Carlos Diegues cunhou em 1978 o termo "patrulhas ideológicas" em referência a alguns críticos de cinema de esquerda que tentariam controlar a produção artística, a partir de suas motivações políticas. O ponto de atrito inicial nasceu após os comentários negativos da imprensa alternativa sobre Xica da Silva (1976). O artigo examina a recepção crítica dos jornais ao filme de Diegues, fornecendo especial atenção aos textos que criaram o debate. Naquele momento, a cultura do nacional popular era usada como critério de análise para os filmes brasileiros. Elucidamos em primeira mão os bastidores e a polêmica interna causada por Xica no jornal alternativo Opinião, num período de crescente fragmentação da esquerda.

Palavras-chave: Xica da Silva. Carlos Diegues. Crítica cinematográfica.

\begin{abstract}
The filmmaker Carlos Diegues coined in 1978 the term "ideological patrols" in reference to some leftist film critics who try to control the artistic production from their political reason. The initial sticking point was born after the negative reviews of the underground press about Xica da Silva (1976). The article examines the critical reception of Diegues film in the newspapers, giving special attention to the texts that created the debate. At that time, the national popular culture was used as an analysis criterion for Brazilian films. We elucidate in firsthand the backstage and internal controversy caused by Xica in underground newspaper Opinião, in a period of increasing leftist fragmentation.
\end{abstract}

Keywords: Xica da Silva. Carlos Diegues. Film Criticism

\section{Introdução}

A polêmica em torno das patrulhas ideológicas surgiu em 1978 durante o lançamento de Chuvas de verão (1977) de Carlos Diegues, quando o cineasta concedeu uma entrevista a Pola Vartuck do jornal O Estado de São Paulo (Diegues, 1978). Durante a conversa, o diretor apresentou-se como defensor da liberdade de criação artística, enquanto a esquerda radical tentaria impor com seu partidarismo uma censura tão nefasta quanto a do regime militar. Diegues definia a patrulha como uma "polícia ideológica" encarregada de vigiar a produção dos artistas e de submeter a arte aos imperativos políticos. Em pouco tempo, a terminologia foi incorporada pelo meio ambiente cultural da esquerda e os artistas passaram a declarar-se patrulhados tanto pela esquerda quanto pela direita. Se o termo ganhou novas acepções com o desenrolar do debate

1 Pesquisa financiada pela Fapesp. 
(Hollanda; Messeder, 1980), os destinatários das condenações de Diegues eram os críticos dos jornais alternativos Opinião e Movimento,que reprovaram Xica da Silva (1976) dois anos antes. Exatamente a imprensa alternativa, que sofria com a interdição feroz do regime, era acusada de colocar em prática a censura política. Foi através desses meandros que a crítica de cinema tornou-se a porta de entrada de uma das maiores polêmicas culturais entre artistas e intelectuais de esquerda no final da década de setenta.

O tema de Xica da Silva envolvia sexualidade, representação da mulher negra e escravidão, um prato cheio para as divergências internas da esquerda daquele momento. Era através da história da escrava alforriada e poderosa que Carlos Diegues tentava revelar as estratégias de subversão dos oprimidos. Depois de realizar Ganga Zumba (1963-1964), o diretor deixava de lado a temática entre senhor e escravo para se dedicar à inversão: mostrar Xica como mulher influente por causa de seus dotes sexuais. Quase quarenta anos depois, em seu livro de memórias, Carlos Diegues (2014) explica que seu desejo era romper com a melancolia de sua geração e proclamar o projeto de um cinema brasileiro nacional popular ${ }^{2}$. Ele escolheu o enredo de Xica como uma "fábula política", enquanto os personagens representavam alguns atores sociais daquele momento: o imperialismo brutal no conde português, a burguesia nacionalista e covarde no contratador, as classes médias serviçais no sargento, no tendente e no pároco, o intelectual revolucionário no jovem inconfidente, e por último, o povo em Xica. Por causa da censura, o cineasta recorria à carnavalização ${ }^{3}$ para transmitir ideias proibidas. Tentando fugir do pessimismo comum aos anos de chumbo, o filme funcionava como uma preparação para a abertura política,

2 A referência de Carlos Diegues ao nacional popular faz parte de uma cultura política engajada. Encarregada de "ir ao povo", essa intelectualidade buscava a expressão simbólica da nacionalidade de tal forma que o nacional e o popular se refletissem e dessem sentido um ao outro. Marcos Napolitano (2001a) demonstrou como o nacional popular transformou-se ao mesmo tempo numa cultura política engajada, numa política cultural da esquerda e num projeto identitário, não só dos artistas e intelectuais ligados ao partido comunista, mas do setor nacionalista e de esquerda. Todos eles incorporaram a tarefa de ir ao povo e de articular esta consciência. Depois do golpe militar, o nacional popular tornou-se o núcleo ético e político de construção de uma consciência de resistência, que tinha como um dos pilares centrais a defesa da ocupação do mercado através de uma linguagem acessível e a afirmação do intelectual como arauto do povo. O conceito é crucial para este debate porque os comentários da crítica de cinema sobre Xica da Silva tangenciam a cultura do nacional popular, como veremos.

3 A carnavalização delineada por Mikhail Bakhtin apoia-se na tradição literária que transpõe o espírito carnavalesco para a arte (Fiorin, 2006). Tomando como base a inversão social dos papéis no carnaval, a força corrosiva do riso procura a libertação do medo e a explosão de liberdade sem admitir qualquer tipo de dogma ou autoritarismo. Através da falta de verossimilhança, das condutas excêntricas de personagens em estado de espírito anormal, do gosto por escândalos e da mistura entre a cultura erudita e a popular se pretende abolir as hierarquias sociais e incitar o público a se exprimir numa atitude criadora livre. 
trazendo um contraponto de alegria e prazer no enredo. Para Diegues, Xica não falava de escravidão, mas do "direito à felicidade".

Contudo a inversão bakhtiniana entre oprimido e opressor e a vontade de fazer uma crítica multifacetada ao poder não foi bem vista por alguns críticos da imprensa alternativa. Por exemplo, três articulistas de Opinião acusaram o diretor de usar o apelo da comédia erótica para conquistar o público, trazendo uma visão da mulher negra como objeto sexual. Desgostoso dessa recepção negativa, o cineasta viu um episódio de autoritarismo desses críticos, numa tentativa de manter o fantasma da instrumentalização política nas artes. Para ele, a "esquerda minoritária" não entendeu Xica e preferiu condenar o filme numa atitude "moralista" porque só aceitava mostrar o sexo no cinema como sintoma do mal estar da sociedade (Diegues, 2014, p. 379).

Diferente dos comentários da imprensa alternativa, Xica foi um grande sucesso de público. Na já citada entrevista para o Estadão, Carlos Diegues afirmou que o filmeteve uma recepção crítica quase unânime no Rio de Janeiro e em São Paulo. É preciso examinar esse dado detidamente. Por exemplo, em Veja, Sérgio Augusto (1976) elogiou a beleza do filme e a interpretação de Zezé Mota, mas observou um apagamento meticuloso dos traços subversivos de Xica. Ela representaria o inconsciente de uma revolução cujo alcance não se teve condições de assimilar.

José Carlos Avellar dedicou ao filme de Diegues mais de um artigo no Jornal do Brasil ${ }^{4}$. No primeiro deles, chamado Luz, cama, ação, o crítico analisou a imagem de Xica recém-alforriada na companhia dos escravos, percorrendo as ruas da cidade. Numa explosão de alegria intensa, eles dançavam em direção da plateia, mas o plano terminava quase sem movimento e em silêncio. $A$ decomposição da cena era o primeiro passo para Avellar avaliar o mecanismo de identificação com a personagem. Não era no conteúdo, mas no ritmo interno das cenas, nas cores, no espetáculo e na expressão corporal que o público conseguia apanhar informações no contato com as imagens. Alguns espectadores poderiam até aproximar-se ou incorporar a visão de mundo da personagem, tomando a emoção como princípio básico da obra. Em Subversivos, Avellar apontava a existência de um conjunto de filmes feitos nos últimos dez anos nos quais o conhecimento não podia ser utilizado para impulsionar uma ação transformadora do mundo. Assim, a solução para os personagens era a indiferença ou o refúgio no silêncio. Portanto, tanto o gosto bárbaro quanto a

4 Avellar, José Carlos. s.d. Pasta sobre Xica da Silva da Cinemateca Brasileira. Os dois artigos compõem uma prévia para a análise publicada anos depois no livro O cinema dilacerado (Avellar, 1986). 
beleza destruidora de Xica serviriam como uma forma eficiente para exteriorizar os silêncios e violências sofridas numa sociedade repressiva. Em contraposição à solenidade, bons modos e hipocrisia, Xica devolvia gestos exagerados e soltos, muita avacalhação, deboche e desrespeito.

Não foi só Avellar quem traçou um paralelo entre Xica e a carnavalização. O antropólogo Roberto da Matta (1976) aprofundou essa ideia num artigo publicado em Opinião. Se os estudos acadêmicos realçam a análise do poder, Diegues investigou a fundo os dois lados da "obediência", explicou o antropólogo. Isto é, as formas pelas quais o poder dos fracos, com seu viés residual e compensatório, se contrapõe ao poder dos fortes. Tanto Xica, quanto os marginalizados ou exilados do sistema atualizariam uma prática corporal ligada ao escândalo, ao poder de rir e de dar alegria. Aproveitando-se do clima carnavalesco, o filme deslocava e invertia o forte pelo fraco, subvertendo a ordem do mundo. Assim a grandeza de Diegues, segundo da Matta, seria conseguir revelar a "complementaridade" e "harmonia compensatória" do forte e do fraco. Comentando indiretamente a recepção negativa de alguns críticos, da Matta (1976) tocou num ponto crucial sobre o deslocamento dos textos para o lado da moral. A polêmica sobre o filme não nasceu devido ao romance com o senhor, mas por causa da ascensão e uso social que Xica fez desse poder. "É esse o momento perigoso e que indica a hora de moralizar", ressaltou da Matta (1976, p. 19).

Se críticos conceituados como Sérgio Augusto, José Carlos Avellar e Roberto da Matta elogiaram o filme, Jairo Ferreira e Leon Cakoff ressaltaram ainda durante a estreia a comparação com a comédia erótica. Na Folha de São Paulo, Jairo Ferreira (1976) observou o uso do repertório da pornochanchada, mas sem o mau gosto do gênero. Olado positivo dessa escolha era a possibilidade de conquistar o público, mas esse ganho vinha lado a lado a um sacrifício da riqueza político-ideológica. Para Jairo Ferreira, Diegues evitava não só a temática entre senhor e escravo, mas o "deboche total" por representar o perigo de uma atitude udigrudi. No Diário de S.Paulo, Leon Cakoff (1976) assinalou a tendência de Xica ao erotismo e à comédia erótica, numa tímida e infeliz alegoria que contribui com a imbecilização das plateias. Se há belos momentos plásticos, a mulher negra é representada como alguém que precisa se engraçar com o patrão para subir na vida, explica Cakoff.

Vale ressaltar que os artigos de Ferreira e Cakoff foram publicados quase um mês antes da repercussão em Opinião. Portanto, a imprensa alternativa não inaugurou o debate contrário ao filme; apenas o consolidou. Além desses artigos, os comentários mais desfavoráveis a Xica possuem um ponto em comum. Os articulistas eram figuras menos conhecidas no campo intelectual, 
o que permitia uma liberdade maior para condenar um cinemanovista, cujo grupo desfrutava de um espaço hegemônico na imprensa. Esses críticos são os responsáveis pela apreciação negativa ao filmetanto na grande imprensa, quanto na imprensa alternativa. Com o título Xica da Silva, um cronista anônimo do Jornal da Manhã (1976) assinalou a presença de um primitivismo no "manejo da linguagem cinematográfica", "desbancando para o ridículo". As diatribes não paravam por aí. Protegido pela não identificação de sua pessoa, ele taxou Carlos Diegues de "ruindade" de diretor e "líder da máfia" que domina a Embrafilme. Confundido o viés carnavalesco com a chanchada, o artigo aponta indiretamente para a articulação entre cinemanovistas e Estado via Embrafilme, que era vista algumas vezes nos jornais como forma de cooptação do regime. $O$ Jornal da Tarde acompanhou essa tendência com Telma Martina (1976). Falando ao público na primeira pessoa, ela declarou sem ressalvas que não sentiu a tão aclamada "alegria" em Xica, somente na música. Enquanto isso, Oswaldo Mendes (1976), no Última Hora, apontou um filme tão "inútil" e "pitoresco" quanto qualquer "narrativa folhetinesca".

O debate em torno de Xica teve uma temporalidade bastante ampliada. Por conta da reexibição da obra em 1979, Malu Maranhão (1979), no mesmo $U H$, viu somente uma pornochanchada "disfarçada em rica produção" num tipo de "samba enredo" para turista estrangeiro ver. A jornalista narra que a irritação com o filme começou por causa de uma conversa prévia com Carlos Diegues. Ele teria realçado a existência de várias "implicações feministas" inexistentes no material fílmico. "Tirando o refrão não sobra nada", explica Malu. Um dos comentários revela o peso do cinema engajado sobre os críticos. Maranhão compara alguns cineastas que escolheram como tema a situação da América Latina, enquanto Diegues preferiu o rótulo de país tropical exótico com negra bonita para turista ver. E termina: "e para que não me chamem de patrulheira, já vou avisando que não estou cobrando ideologia nenhuma. Apenas um pouco de coerência".

Para alguns críticos, o deboche, a avacalhação e a sensualidade de Xica seriam uma forma de aderir à pornochanchada. Confunde-se aqui o mostrar na tela como forma de aderir aos personagens representados. Nesses casos, houve também uma tendência à polarização do viés sexual. Uns veem o erótico como indício negativo de libertinagem, num viés conservador. Assim se confundia o mecanismo da carnavalização com uma maneira de compactuar com a produção massificada. Esses comentários revelam a existência de alguns imperativos que atrelam a obra de arte a uma função, seja social ou política. Nesses casos, a crítica de cinema esbarra no conceito de arte como responsabilidade social do artista ou como julgamento de ordem moral. Esses quesitos foram superados 
na história da arte ao longo do século XIX com o primado da forma, a ausência de função e o desprezo à ideia de que a arte deve desempenhar uma função social ou política (Bourdieu, 1996). Do outro lado, como vimos, alguns críticos atrelaram o erótico a uma forma de enfrentamento às avessas ao sistema, a partir do conceito de carnavalização.

Não foi só em torno da carnavalização e da pornochanchada que a crítica de cinema se polarizou, mas também através do conceito da cultura do nacional popular. Mais ou menos quinze dias após a estreia do filme, o jornal alternativo Movimento publicou o texto de Luís Roncari e Wolfgang Maar (1976). Os autores eram mestrandos da Universidade de São Paulo e depois se tornariam catedráticos da mesma instituição. Polemista, o artigo sugere que Cacá Diegues era um instrumento ativo ou passivo do projeto do ISEB (Instituto Superior de Estudos Brasileiros), fazendo convergir no filme tanto o nacionalismo de esquerda, quanto o de direita. Desinteressado da inversão bakhtiniana de papeis, o texto concentra-se no enredo de Xica, na representação entre senhor e escravoe na presença da ideologia. Para Roncari e Maar, a ideologia "pretensamente tropicalista" põe de lado o conflito da escravidão e tematiza somente a relação entre portugueses e colonos. A partir de um viés da crítica marxista, os autores demonstram como a ideologia incide sobre o argumento do filme. Dessa forma, Xica apontaria a possibilidade da existência de uma escravidão mais branda por causa da bondade dos senhores brancos.

Na mesma página da crítica de Roncari e Maar, um segundo texto chamado A história do Brasil segundo Cacá Diegues (1976) aprofunda a ligação entre Carlos Diegues, o ISEB e a cultura do nacional popular. Sem trazer a designação dos autores, quiçá o artigo tenha sido escrito pelos mesmos articulistas. Deixando de lado a discussão artística, a referência indireta é o livro inaugural de JeanClaude Bernardet, Brasil em Tempo de Cinema (1967), que traçou pela primeira vez um paralelo entre os filmes, a classe social dos cinemanovistas e sua visão de mundo. O livro causou grande polêmica por colocar em xeque a pretensão de alguns cineastas em se ver como geradores autênticos da cultura popular. Enquanto Bernardet (2007, p. 80) ressaltou como positivo o surgimento de uma liderança da própria comunidade em Ganga Zumba, o artigo de Movimento vê na temática do líder negro apenas uma postura mística, romântica e populista. O jornal alternativo relacionou esse dado com a presença de um cineasta da classe média com uma concepção de cultura popular atrelada ao nacional popular. Isto é, que acredita em sua missão de produzir a cultura popular. Trata-se de um típico argumento não só de Brasil em Tempo de Cinema, mas dos opositores da cultura do nacional popular daquele momento. O ponto de 
atrito para Movimento era partir de uma visão branca do quilombo e tomar a comunidade negra como forma de sublinhar os traços de nossa nacionalidade.

Quase dez anos depois do lançamento do livro de Bernardet, o artigo de Movimento mantinha-se sintonizado com essa perspectiva e estabelecia uma continuidade entre a visão de mundo dos filmes do Cinema Novo com a classe média que o produz. Essa ideia permanece implícita no artigo, mas ela é o centro irradiador da argumentação. Carlos Diegues e os colegas cinemanovistas com seu nacionalismo "exagerado" e datado ainda estariam próximos ao ISEB. Por esse motivo, os filmes apregoavam uma visão "elitista" de mundo, enquanto os cineastas viam-se como dotados do poder de educar líderes para "assumir seus postos no seio do povo". O artigo sem assinatura completa a crítica de Roncari e Maar sobre os valores do nacional popular, especialmente sobre o papel preponderante dado ao intelectual-cineasta em relação às mudanças do país. A oposição a esses conceitos ocorre porque a cultura do nacional popular menosprezaria os conflitos sociais internos e a participação popular. Diegues e sua geração perpetuariam esse quadro, ao invés de mudá-lo. O ponto de contato entre o filme de época e o contexto político da resistência fica patente quando o articulista anônimo declara que não aceita a representação do Brasil colonial e escravocrata como exemplo para as "perspectivas brasileiras de 1976". Contudo, o artigo não chega a analisar como se dá esse processo em Xica da Silva e prefere condenar a obra de Diegues em conjunto.

Um mês após o lançamento de Xica, a recepção do jornal alternativo Opinião também levou em conta um debate sobre o nacional popular. Os comentários negativos de três críticos podem ser incluídos no rol de autores pouco conhecidos naquele momento. Como em Movimento, os textos realçaram uma crítica à cultura do nacional popular, com a qual Carlos Diegues estava mais ligado. Nestes casos, a presença deste referencial torna-se uma metodologia para os críticos, deslocando a análise interna do filme para a discussão da cultura popular e do papel do intelectual. Analisamos os textos de Opinião de forma mais detida pelo teor interno e porque eles motivaram a polêmica com Diegues, repercutindo até mesmo em outros jornais do período. Não procuramos por uma verdade dentro da materialidade do filme, afinal o objetivo de Diegues nada teve a ver com a percepção dos críticos do jornal. Procuramos entender as razões do posicionamento dos colaboradores de Opinião, porque o lugar de onde eles falam altera a fruição e o entendimento do filme. Nossos comentários não são sobre Xica da Silva enquanto obra, mas sobre o surgimento de novos atores sociais na crítica de cinema.

O caso das patrulhas ideológicas ao qual Xica abre passagem surge como sintoma de uma crise maior na identidade da intelectualidade (Napolitano, 
2006; Napolitano, 2011). A pretensão anterior do cineasta de se ver como portavoz das classes populares dava demonstrações de esgotamento no contexto da abertura política. Como sinal desses novos tempos, emerge em Opinião um debate sobre o papel do intelectual-cineasta em relação à cultura popular. Três críticos do jornal não aceitaram um branco colocar-se como porta-voz das classes populares, apontando o quanto a crítica de cinema girava em torno da crise da figura do intelectual engajado.

Com a manchete Xica da Silva - Genial? Racista? Pornochanchada? (1976), o jornal apresenta um conjunto de textos de especialistas. Enquanto o escritor Antonio Callado (1976) ${ }^{5}$ e o antropólogo Roberto da Matta elogiaram Carlos Diegues, a oposição foi mais forte e se fez presente tanto pelo cineasta Carlos Frederico, como pela historiadora Beatriz Nascimento ou pelo sociólogo Carlos Hasenbalg. Sem apresentar um crítico como seu legítimo representante, Opinião refere-se aos artigos como "visões" dos convidados. A pauta teria surgido para aprofundar as polêmicas causadas desde o lançamento de Xica.

Logo de cara o título escolhido pelo cineasta marginal Carlos Frederico (1976) já provocava polêmica: Abacaxica. A palavra era comum na crítica de cinema das décadas anteriores, quando a fruta tropical convertia-se em sinônimo de uma baixa qualidade do cinema brasileiro. A motivação do crítico para escrever o texto teria sido a "unanimidade" de opiniões de todos os lados sobre o filme, tomando-o como um "marco" e "caminho" para o cinema brasileiro. 0 artigo começa com uma comparação infundada entre Cinema Novo e comédia erótica porque tudo "gira em torno da cama e dos extraordinários dotes" da personagem: "Xica da Silva, de Cacá Diegues, é o casamento oficial do cinemanovo com a pornochanchada, após o noivado (digno) de Guerra Conjugal, de Joaquim Pedro." O texto é repleto de provocações ao Cinema Novo e tenta provar que a linguagem "excessivamente falada" do movimento foi copiada pelos personagens esquemáticos da pornochanchada. Enquanto esta última procura aplicar "certos requintes estéticos cinemanovistas para conquistar um novo 'status' junto ao público", o Cinema Novo "aprende as lições eróticocomerciais da pornochanchada, e tira a roupa". O argumento não se sustenta e pode ser lido como mais uma rixa entre cinemanovistas e cineastas marginais. Contudo, para não o desautorizar em nenhum momento, Frederico não é apresentado como alguém relacionado ao universo da Boca do Lixo. Em meio a comentários bastante negativos, o crítico parabeniza Diegues pelo sucesso da "superprodução bacana". Carlos Frederico não se dedica à análise interna

5 Antonio Callado fez muitos elogios ao filme e frisou o quanto Zezé Mota encarnava a própria pessoa de Chica da Silva. 
detalhada do filme. Observa apenas uma "encenação tão escola-de-samba-praturista-ver", parecida com a de Orfeu do carnaval (1959) de Marcel Camus. Vê um filme teatral, equivocado e cheio de lantejoulas.

$\mathrm{O}$ argumento traz um fundo moralista quando Frederico declara que a personagem central é apenas uma "prostituta assumida que procurava tirar o máximo proveito da sua condição de objeto - esta, a 'grandeza' de Xica". O alvo do texto é a cultura do nacional popular, seja por causa da representação da cultura popular ou da pretensão do cineasta-intelectual em ser arauto do povo. Para Frederico (1976, p. 18), no papel "estúpido" da mulher negra, "Xica imita os ricos, os brancos, os déspotas, os poderosos, e curte adoidado ser como eles - e o filme aplaude, deslumbrado! ". Existe nesse trecho um critério comum a alguns dos textos de Cahiers Du Cinéma daquele período. Trata-se da exigência de o cineasta afastar-se da formação discursiva do personagem ou da trama. Caso contrário, recairia sobre ele acusações de ordem ideológica, como a que acometeu Carlos Diegues.

Mantendo a mesma tendência, Carlos Hasenbalg (1976) procurou pelos significados simbólicos que escapam à intencionalidade do realizador. Aproveitou também para condenar a romantização e os estereótipos negativos sobre o negro que vieram da tradição literária. Na época, o autor era doutorando em sociologia e ligado ao marxismo universitário (Napolitano, 2011). Sem localizar nada de novo no filme, Hasenbalg frisou como a potencialidade libertadora e criativa do erótico foi confundida com deboche, libertinagem e oportunismo sexual.

O texto mais polêmico de Opinião é o da historiadora e ativista do movimento negro Beatriz Nascimento (1976). Duas afirmações desse artigo motivaram a declaração de Carlos Diegues sobre as patrulhas ideológicas. $O$ primeiro trecho em questão é realmente uma diatribe:"O senhor Carlos Diegues é senil em sua obra-prima (porque eu espero que ele não confeccione outra e já Ihe concedo o fim da sua carreira cinematográfica)." Na sequência, Beatriz Nascimento (1976) declara: "Quanto a sua penetração enquanto discurso e comunicação o condenaríamos ao 'índex' das obras proibidas". Foi desta parte do artigo que Carlos Diegues tirou a comparação entre Beatriz Nascimento e a ação da censura, na chamada patrulha ideológica. Nem os textos mais radicais de Opinião chegaram a incluir a produção hollywoodiana no Índex. A radicalidade se baseia num acirramento de posições, que tem relação com o lugar de origem. A autora do texto emerge ao mesmo tempo como historiadora e como o próprio sujeito social; isto é, como a mulher negra ofendida pelo filme. Não se trata da opinião de um crítico de cinema. Esse é o principal motivo do 
atrito. Para Beatriz Nascimento (1976), Xica da Silva tem um "humor barato e grosseiro em cima de estereótipos mais vulgares a respeito desse povo".

AargumentaçãodeNascimento (1976) nãogirasóem torno danecessidade de veracidade histórica na arte, mas reclama a falta de conhecimento da cultura negra. Ela se incomodou com a conversão do comportamento típico de mulher africana "prepotente" e "dinâmica" em mito da sexualidade. A autora não falou em nome da veracidade histórica somente. Ela exigiu que o intelectual-cineasta respeitasse os mitos populares. É como se parte da cultura popular surgisse na figura de Beatriz Nascimento para reclamar ao realizador a representação do povo negro. O debate não toma o ponto de vista da discussão artística, porque a motivação é a do movimento social, que luta para se livrar dos estereótipos mostrados no cinema. Para ela, Diegues não deveria ter a pretensão de abordar tais temas porque não faz parte deste universo. Aqui há um limite muito tênue e polêmico entre a autonomia da arte e a recepção do público. Para Nascimento, colocar na tela um assunto tabu sem criticá-lo é endossar os preconceitos. Neste caso, o imperativo político estava à frente da autonomia estética.

Para provar a argumentação, Beatriz Nascimento (1976) vai até o enredo do filme. Ela coloca em prática a metodologia de Opinião de analisar o discurso político através do enredo das obras. Ao olhar somente para a trama do filme, a autora não analisa outras significações. Foge da discussão estética. Vê um reforço do "mito do senhor bondoso" com os escravos que esconde o conflito racial, porque o protetor branco resolve todas as injustiças feitas contra Xica. A consequência é mostrar o negro como figura "passiva" e "dócil", "incapaz de pensar". A autora vê também o personagem de Walmor Chagas como prolongamento da figura do diretor, dividido entre o amor, o povo e a coroa, no papel de um intelectual burguês. Para Beatriz Nascimento (1976), o cineasta não está habilitado a falar pelo povo. Pela primeira vez naquele jornalse ouviu a voz de alguém atrelado à própria cultura popular. Ela evocou sua condição de mulher negra e militante do movimento para falar com mais autoridade do que Diegues. É como se fosse mais importante no debate seu lugar de origem do que a prática artística do diretor. A historiadora coloca-se como ator social legítimo, não como intermediária. Não era só o papel do cineasta que Nascimento condenava, porque ela chegou a problematizar também a cultura popular que deveria ser mostrada em papel relativo. A autora urge por uma representação do povo a partir de contradições para fugir de uma perspectiva de autenticidade do popular. Por fim, ela declara: "o senhor [Carlos Diegues] me faz pensar que sua classe de acordo com a sua tradição está dentro da Casa Grande jogando restos de comida na Senzala. [...] Por favor, nos esqueça, a nós negros" (Nascimento, 1976). Isto é, o negro não precisa do intelectual porque 
pensa sozinho. Neste texto, Beatriz surge como um preâmbulo do povo como ator social na crítica de cinema. Reivindica sua autoridade para contestar um cineasta. Dois anos antes, ela fez o prelúdio de um debate que explodiu em 1978 com a eclosão dos movimentos sociais. Naquele mesmo ano, houve, por exemplo, a unificação dos movimentos negros (Singer, Brant, 1982). Neste caso em especial, o semanário de Fernando Gasparianserviu como uma ponte para o início de uma discussão na opinião pública. Era em instituições sociais como esta, que muitas associações encontraram uma primeira acolhida para abrir um espaço de atuação.

Se Carlos Diegues achou que os temas da subversão da ordem estabelecida e da contracultura seriam vistos como algo positivo entre os críticos de cinema, os convidados do jornal Opinião não viram prazer algum no filme. Para os três críticos do semanário contrários a Xica, a questão principal era a representação da cultura popular e a oposição ao intelectual atrelado à cultura do nacional popular. Em oposição à análise da carnavalização, os citados articulistas colocavam em prática alguns pressupostos da crítica marxista, voltada a desmistificar a ideologia latente dos filmes (Eagleton, 2011). Se os intelectuais e artistas dos anos setenta definiram as patrulhas ideológicas com os mais diversos sentidos, aqui é possível trazer mais uma nuance. A condenação de Opinião não partiu de nenhum núcleo ortodoxo da esquerda, mas de sua oposição, seja no Cinema Marginal, no movimento social ou na vertente acadêmica representada por Carlos Hasenbalg (1976). Talvez a riqueza do filme tenha sido permitir essas duas leituras. Contudo, os atores sociais envolvidos no debate não são, de forma alguma, os "patrulheiros"-padrão. Ao contrário. Diegues enxergava um patrulheiro, mas eclodia na sua frente uma representante do movimento negro. Falando com suas próprias rédeas, Beatriz Nascimento não estava interessada em discutir a crítica de cinema enquanto arte, mas como forma de reivindicação política.

A disposição balanceada de textos contrários e a favor do filme criou no jornaluma polêmica bem fundamentada. Portanto, Opinião não foi patrulha, porque a equipe da seção de cultura estava exatamente no sentido contrário. Como vimos, não foi só em Opinião que Xica da Silva recebeu comentários desfavoráveis. A diferença é que os artigos do jornal de Fernando Gasparian repercutiam muito na imprensa e no debate cultural daquele período. Nesse sentido, Opinião desencadeou e uniu num só coro uma discussão que já estava diluída no espaço público sobre a cultura do nacional popular e sobre o papel do intelectual como arauto à frente do povo.

Os artigos de Opinião reverberaram na esfera pública com uma temporalidade prolongada. O debate começou com os leitores da imprensa 
alternativa, que se manifestaram no jornal Movimento. Três missivistas incorporaram o argumento de Beatriz Nascimento de que a relação entre senhor e escravo foi deixada de lado. O foco nesse aspecto reflete o quanto o público leigo geralmente frisava o enredo do filme, deixando de lado o viés estético. A tendência era de fragmentação das opiniões, indo de encontro ao que acontecia na esquerda. Luís Otávio Teixeira (1976) defendeu o filme como registro factível da situação dos negros, porque sem seu protetor branco, Xica perdeu todas as regalias. José Inácio Correia Fortes (1976) teve um alcance de visão maior e percebeu uma mudança no panorama cultural brasileiro. Ele é um exemplo da máxima postura de hesitação. Elogia a cultura do nacional popular frente à descaracterização da produção estrangeira, mas insiste na falta de clareza do diretor sobre seus objetivos. O futuro professor da Universidade Federal da Paraíba, Enoque Feitosa Sobreira Filho (1976), compactuou com a leitura de Beatriz Nascimento sobre a visão negativa da mulher negra no filme. O tom de diatribes em torno de Xica também caracterizou o comentário de Tarso de Castro sobre a repercussão do caso. Com grande humor, ele ignorou a argumentação de Beatriz Nascimento e se concentrou nas incoerências de Carlos Frederico. Chegou a definir o texto de Frederico como um "bestialógico de grande competência numa estupidez impressionante".

Por fim, o debate extrapolou o campo do cinema e chegou até Gilberto Freyre no Diário de Pernambuco (1977). Um ano depois da publicação dos textos em Opinião, uma leitora Ihe enviou um recorte de jornal com o artigo de Beatriz Nascimento. Instigada pelo texto, ela queria saber se era verdade que o filme estava mais ao lado da casa grande do que da senzala. Gilberto Freyre ficou literalmente em cima do muro, mantendo sua postura direitista naquele momento. Ele elogiou tanto o texto de Beatriz Nascimento quanto o filme de Carlos Diegues. Declarou que não tinha distanciamento suficiente para responder à pergunta porque era o autor do livro citado.

Se a repercussão de Xica na opinião pública foi grande, ela não chegou a ser maior do que a polêmica interna causada em Opinião. A ideia da coletânea não surgiu de uma reunião de pauta por causa do lançamento do filme, mas porque Beatriz Nascimento e Carlos Frederico foram procurar a redação do jornal. Ela reclamou que o filme mostrava a mulher negra ascendendo socialmente a partir da cama. Ele detestou Xica por ser um "cartão postal". Em entrevista ${ }^{6}$, o editor de cultura de Opinião, Júlio César Montenegro Bastos (2014), conta que ficou "encantado" com a revolta de Beatriz. Viu no episódio a possibilidade de mostrar no jornal como pensava a mulher negra. Ele prometeu publicar o texto

6 Entrevista concedida ao autor em 2014. 
se Nascimento escrevesse. Afinal, o próprio Montenegro havia detestado o filme "vitrine" de Carlos Diegues.

A disputa interna causada por Xica da Silva no jornal foi a mais forte da seção cultural, mas não foi a primeira, nem a última. A postura editorial instituída por Montenegro naquele momento previa polemizar e questionar a produção cultural. A posição causava vários conflitos com o proprietário do jornal, Fernando Gasparian. Se a imprensa falava bem do filme, Montenegro queria criar um contraponto para fazer o leitor adquirir consciência da dinâmica interna da crítica cultural. Se a redação estava unida por causa da luta contra a ditadura, a equipe de Tendências e Cultura lutava pela autonomia de poder criticar quem quisesse. Como Gasparian não dava carteira assinada e pagava salários muito abaixo do mercado, os colaboradores julgavam-se donos do semanário alternativo, investindo numa prática de autogestão.

O dono do jornal não queria publicar os textos para não ofender Carlos Diegues. Ele ficou "irritadíssimo" com a palavra Abacaxica do texto de Carlos Frederico (1976). Montenegro decidiu publicar a coletânea contra a vontade do proprietário, indicando a existência de uma linha de manobra interna. Para contrabalançar os comentários negativos, Fernando Gasparian solicitou dois artigos dos "amigos" Antonio Callado e Roberto da Matta para defender o filme. O equilíbrio entre textos favoráveis e desfavoráveis decorre desse processo. Montenegro explica que Opinião sempre dava muita visibilidade aos colaboradores e com Xica não foi diferente. Os textos geraram muita repercussão no debate cultural. $\mathrm{O}$ ex-editor de Opinião relembra que Carlos Diegues ficou "irado" com a cobertura e mandou uma carta ao jornal, impublicável por causa dos palavrões. Polemista ao extremo, Montenegro queria publicar a resposta do cineasta, mas o dono do jornal não deixou? ${ }^{7}$. Se Beatriz Nascimento, Carlos Frederico e Fernando Gasparian faleceram, ainda nos anos noventa, o proprietário de Opinião concedeu uma entrevista a VaniKenski (1990) e explicou que era obrigado a interferir no dia-a-dia da redação, porque a equipe criticava pessoas ilustres e aliadas do jornal na luta contra a ditadura.

Acima de tudo, a polêmica de Xica da Silva na imprensa não aponta para uma discussão atrelada ao campo específico do cinema, mas para as divergências internas da esquerda sobre as maneiras de realizar a resistência. No centro do debate estava a cultura do nacional popular. Se ela ainda era muito forte no período, passava a sofrer com uma contestação crescente por causa da pretensão

7 Indiretamente encontramos numa entrevista de Glauber Rocha (Hollanda; Pereira, 1980) uma menção à existência dessa missiva. O cineasta contou que a carta foi devolvida por Gasparian com um bilhete, afirmando que a resposta não poderia ser publicada no jornal, nem ficar nos arquivos pessoais dele. A proposta da carta, segundo Glauber Rocha, seria criar um debate ideológico em outro nível. 
do intelectual em ser arauto do povo e de se ver como produtor autêntico da cultura popular. Entre as duas pontas, os cinemanovistas estavam muito mais próximos da cultura do nacional popular. Fato é que na última fase de Opinião, crescia na seção cultural uma divergência acirrada em relação a esse conceito. Daí o conflito interno quando as matérias envolviam grandes nomes dessa cultura, não só Cacá Diegues, mas Paulo Pontes, Chico Buarque, Gianfrancesco Guarnieri. Porém nem sempre essas matérias chegaram até o público, porque foram vetadas interinamente, conforme o relato dos colaboradores.

Não se pode dizer que Fernando Gasparian fosse favorável ao nacional popular por uma preferência pessoal. Montenegro esclarece que o dono do jornal não queria enfrentar esse grupo porque "os medalhões da esquerda" eram um "jogo pesado". Ele usa o termo em referência ao conto Teoria dos Medalhões de Machado de Assis (1994) para mencionar os que usam a publicidade, a imprensa e as amizades como fim de se consagrar na política. O ex-editor relembra que os "medalhões da esquerda" "foram para cima do Gasparian nos esculhambando". A longo prazo, a consequência desse processo foi a exoneração de Montenegro meses depois. Se a principal motivação da demissão passava pelo episódio de Xica da Silva, esse não foi o único atrito entre a redação do jornal e Fernando Gasparian. Teria sido esse acúmulo de casos de oposição ao nacional popular ao longo dos últimos dois anos do jornal o responsável pela demissão do editor de cultura. Gasparian chamou Montenegro para dizer que "eles" não continuariam a escrever, se o editor de cultura ficasse no semanário. Cheia de "apadrinhamentos", a cena cultural brasileira "preferiu acertar com o patrão a minha demissão", nos conta o ex-editor. Quando Gasparian convidou Montenegro a sair, muitos colegas deixaram o semanário em solidariedade.

Os atritos não aconteciam somente na seção cultural porque as questões de fundo salarial também pesavam (Kucinski, 1991). Enfrentando forte censura e a oposição da redação, Gasparian mandou embora os principais editores antes de fechar o jornal. Segundo Montenegro, a demissão foi o resultado da "aliança de forças em torno de Gasparian". A pressão era conjunta. A ação não foi feita por uma pessoa em especial, porque a força vinha da união entre eles. Além disso, figuras importantes do meio cultural escreviam de graça e Gasparian pedia muitos textos. Ao mesmo tempo, o proprietário de Opinião respeitava seus aliados e não queria prescindir dessas relações. $O$ intuito da demissão era "matar uma semente que estava nascendo", explica Montenegro. Gasparian sentia que "perdia o controle" porque "as pessoas estavam se juntando e formando uma corrente", que não tinha como principal objetivo somente a luta contra a ditadura. A redação levantava outras bandeiras, como a oposição ao nacional popular. De acordo com o ex-editor de cultura de Opinião, o grupo não 
queria dividir porque estava no comando, mas o processo de fragmentação da esquerda já estava em curso.

A preferência ao núcleo do nacional popular no jornal tinha relação com o status do grupo no período. Seria "desgastante" enfrentá-lo, explica Montenegro. Gasparian queria caracterizar Opinião somente como uma frente anti-ditatorial. Isto é, ele não queria dar espaço a outros pensamentos além dos pontos comuns da Frente de oposição ao regime militar. A proposta inicial era ocultar as divergências internas da esquerda para não atrapalhar a luta contra o regime militar. Contudo ao longo dos anos setenta algumas bandeiras consensuais como a cultura do nacional popular, o papel de destaque do intelectual como arauto da sociedade passaram a ser questionadas cada vez mais no interior da esquerda.

Como exemplo dessa mudança, em 1978, no Última Hora, Jean-Claude Bernardet (1978) questionou a transformação de Xica da Silva de filme de sucesso comercial em obra que exprime os desejos populares. Cacá Diegues forçaria uma confusão intencional entre a "festa do povo" e a do público. Em linguagem clara e direta, o crítico explicava aos leitores que um sucesso comercial pouco dizia sobre a função ideológica de uma obra. Na polêmica das patrulhas ideológicas, Diegues não tornou claro quem eram seus alvos e gerou um clima paranoico de "caças às bruxas", explica o crítico. Além disso, atacou setores aliados e minoritários da esquerda dos jornais Opinião e Movimento como elementos mais "prejudiciais" à criação artística do que a opressão do regime. "Entre Hitler, Mussolini, Geisel, Moscou, Opinião, Movimento, as brigadas vermelhas e o Vigilante Rodoviário existem algumas diferenças históricas", comenta Bernardet. Se Cacá foi alvo de "ataques pouco fundamentados" em Opinião e Movimento, "nem por isso se pode concluir que esses artigos não deveriam ter sido escritos. Eles expressam uma configuração ideológica que existe atualmente no país, mesmo que minoritária" (Bernardet, 1978). Para Bernardet, Xica mexeu com o corpo social e por isso tanto a polêmica criada pelo filme quanto os amores e ódios despertados foram favoráveis. Ao contrário, uma resposta "uniforme" de qualquer tipo seria bem menos produtiva do que a polêmica.

A disputa acirrada sobre Xica revela o atrito da esquerda em torno do nacional popular. Se essa cultura ainda era a fonte de inspiração dos cinemanovistas, para Júlio César Montenegro, o nacional popular era uma ação autoritária e mistificadora, com a pretensão de direcionar os rumos do país e da cultura popular. Esse tipo de reivindicação começava a crescer no ambiente cultural e o elogio indireto de Beatriz Nascimento à experiência cultural do povo frente à diluição do papel do intelectual faz parte desse processo. Foi no microcosmo da crítica de cinema que esses atores sociais impulsionaram 
o episódio das patrulhas ideológicas. Se a polêmica interna de Xica em Opinião permaneceu inédita até a nossa entrevista, Júlio César Montenegro é o personagem oculto desse caso. Foi ele quem permitiu a eclosão na crítica de cinema de atores sociais atrelados ao movimento popular, à vanguarda e à Nova Esquerda acadêmica. Fato é que ideias como esta se encaminhavam para uma futura pauta da Nova Esquerda (Napolitano, 2011), que foi responsável por auxiliar na dissolução do nacional popular. Naquele momento, Montenegro se considerava parte da Nova Esquerda a exemplo do que presenciou na França. Opositor ferrenho do nacional popular, ele tentava colocar em prática as lições francesas, isto é, fazer a crítica interna da esquerda. O episódio de Xica da Silva em Opinião indica um preâmbulo da entrada em cena da Nova Esquerda e de um movimento social no campo do cinema. Embora anteceda o surgimento desses novos atores sociais em 1978, Opinião é parte constituinte desse processo. A partir da polêmica, o jornal alternativo criou um debate plural sobre Xica com várias interpretações, que variavam conforme o local de origem dos articulistas.

A divergência interna de Opinião em torno de Xica da Silva revela o quanto a fragmentação e as disputas internas da esquerda incidiam no dia-a-dia da crítica de cinema nos anos setenta. Ela indica também o quanto um filme reflete as lutas da esquerda e pode influir nos destinos de uma redação. Era através desse contexto que a cultura do nacional popular conseguiu se transformar num grande pilar de análise do cinema brasileiro, mesmo sendo um assunto externo ao campo da crítica.

\section{Referências}

A HISTÓRIA do Brasil segundo Cacá Diegues. Movimento, n. 65, p. 17, 27 set. 1976.

ASSIS, Machado de. "Teoria do Medalhão". In: Papéis avulsos. Obra completa. v. II. Rio de Janeiro: Nova Aguilar, 1994 [1882].

AVELLAR, José Carlos. Luz, cama, ação. Jornal do Brasil. s.d. Pasta sobre Xica da Silva da Cinemateca Brasileira.

. O cinema dilacerado. Rio de Janeiro: Alhambra, 1986.

Brasileira.

AUGUSTO, Sérgio. Uma simbólica e sensata soma de forças. Veja, 8 set. 1976.

BASTOS, Júlio Cesar Montenegro. Entrevista concedida a Margarida Maria Adamatti. São Paulo, 2014. 
BERNARDET, Jean-Claude. A festa de um público não é a festa do povo. Última Hora. 21 set. 1978.

Brasil em tempo de cinema. São Paulo: Cia das Letras, 2007 [1967].

BOURDIEU, Pierre. As regras da arte. São Paulo: Cia das Letras, 1996.

CALLADO, Antonio. Bem nascido e bem dotado. Opinião, n. 206, p. 20, 15 out. 1976.

CAKOFF, Leon. Um deboche mal debochado. Diário de S. Paulo, 23 set. 1976.

CASTRO, Tarso de. Xica da Silva diz mais do que o Jornal Nacional. [s/d.: s/n.: s/l]. Cinemateca Brasileira, Pasta sobre o filme.

DIEGUES, Carlos. Por um cinema popular sem ideologias. Entrevista concedida a Pola Vartuck. O Estado de S. Paulo, São Paulo, p. 16, 31 ago. 1978.

Vida de cinema - antes, durante e depois do Cinema Novo. Rio de Janeiro: Objetiva, 2014.

EAGLETON, Terry. Marxismo e crítica literária. São Paulo: Unesp, 2011 [1976].

FERREIRA, Jairo. Um não à pornochanchada. Folha de S.Paulo, 8 set, 1976.

FIORIN, José Luiz. Introdução ao pensamento de Bakhtin. São Paulo: Ática, 2006.

FORTES, José Inácio Correia. Rumos da cultura nacional. Movimento, n. 73, p. 19, 22 nov. 1976.

FREDERICO, Carlos. Abacaxica. Opinião, n. 206, p. 18, 15 out. 1976.

FREYRE, Gilberto. A propósito de "Xica da Silva”. Diário de Pernambuco, 18 dez, 1977.

HASENBALG, Carlos. Copiando o senso comum. Opinião, n. 206, p. 19, 15 out. 1976.

HOLLANDA, Heloisa B; MESSEDER, Carlos (orgs.). Patrulhas ideológicas. São Paulo: Brasiliense, 1980.

KENSKI, Vani Moreira. O fascínio de Opinião. 1990. Tese (Doutorado em Educação). Faculdade de Educação da Universidade Estadual de Unicamp, Campinas, 1990.

KUCINSKI, Bernardo. Jornalistas e revolucionários - nos tempos da imprensa alternativa. São Paulo: Página Aberta, 1991.

MARANHÃO, Malu. O tropicalismo no cinema nacional. Última Hora, 12 mar. 1979.

MARTINA, Telma. Uma anedota engraçada apenas na trilha sonora. Jornal da Tarde, 16 set. 1976.

MATTA, Roberto da. A hierarquia e o poder dos fracos. Opinião, n. 206, p. 19, 15 out. 
1976.

MENDES, Oswaldo. Jorge Bem e a Xica da Silva, Xica da Silva. Última Hora, 8 set. 1976.

NAPOLITANO, Marcos. Coração civil: arte, resistência e lutas culturais durante o regime militar brasileiro (1964-1980). 2011.Tese (Livre-Docência). Faculdade de Filosofia, Letras e Ciências Humanas, Universidade de São Paulo, São Paulo, 2011. 2001.

.Cultura brasileira: utopia e massificação (1950-1980). São Paulo: Contexto,

.'O caso das patrulhas ideológicas na cena cultural brasileira do final dos anos 70". In: FILHO, João Roberto Martins (org.). 0 golpe de 1964 e o regime militar - novas perspectivas. São Carlos: Edufscar, 2006.

Seguindo a canção - engajamento político e indústria cultural na MPB (1959-1969). São Paulo: Annablume/Fapesp, 2001 a.

NASCIMENTO, Beatriz. A senzala vista da casa grande. Opinião, n. 206, p. 20-21, 15 out. 1976.

RONCARI, Luís; MAAR, Wolfgang. O novo samba enredo de Xica da Silva. Movimento, n. 65, p. 17,27 set. 1976 .

SINGER, Paul; BRANT, Vinicius Caldeira. São Paulo: o povo em movimento. Petrópolis, Editora Vozes, 1982.

SOBREIRA FILHO, Enoque Feitosa. A história de pernas para o ar. Movimento, n. 75, p. 19, 6 dez.1976.

TEIXEIRA, Luís Otávio. A Xica da Silva não é nada sem o seu João Fernandes. Movimento, n. 70, p. 18, 01 nov. 1976.

XICA da Silva. Jornal da Manhã. 7 set. 1976.

XICA da Silva - genial? Racista? Digno do Oscar? Abacaxi? Opinião, n. 206, p. 18-21, 15 out. 1976.

Recebido em: 16/2/2016

Aceito em: 14/3/2016

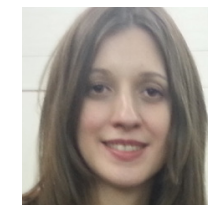

Endereço do autor:

Margarida Maria Adamatti<mmadamatti@hotmail.com $>$

http://lattes.cnpq.br/2629005451704968

Escola de Comunicações e Artes da Universidade de São Paulo (ECA-USP).

Avenida Prof. Lúcio Martins Rodrigues, 443 - Butantã

05508-020 - São Paulo - SP - Brasil 